\title{
Characterization of a biomimetic mesophase composed of non-ionic surfactants and an aqueous solvent.
}

V. Adrien, G. Rayan, M. Reffay, L. Porcar, A. Maldonado, A. Ducruix, W. Urbach, N. Taulier

\section{Supplementary figures}

\begin{tabular}{|c|c|c|c|c|c|}
\hline $\mathrm{V}_{\mathrm{C12E5}}(\mu \mathrm{L})$ & $V_{s 1}(\mu \mathrm{L})$ & $\mathrm{V}_{\mathrm{S2}}(\mu \mathrm{L})$ & $\mathrm{V}_{S 3}(\mu \mathrm{L})$ & $\mathrm{C}_{12} \mathrm{E}_{5}$ fraction (\%) & $\Phi(\%)$ \\
\hline 3 & 30.3 & 66.7 & 0 & 3 & 3.3 \\
\hline 3.5 & 35.5 & 61.1 & 0 & 3.5 & 3.9 \\
\hline 4 & 40.4 & 55.6 & 0 & 4 & 4.4 \\
\hline 4.5 & 45.5 & 50.0 & 0 & 4.5 & 5.0 \\
\hline 5 & 50.6 & 44.4 & 0 & 5 & 5.5 \\
\hline 5.5 & 55.6 & 38.9 & 0 & 5.5 & 6.1 \\
\hline 6 & 60.7 & 33.3 & 0 & 6 & 6.6 \\
\hline 6.5 & 65.7 & 27.8 & 0 & 6.5 & 7.2 \\
\hline 7 & 70.8 & 22.2 & 0 & 7 & 7.7 \\
\hline 7.5 & 75.8 & 16.7 & 0 & 7.5 & 8.3 \\
\hline 8 & 80.9 & 11.1 & 0 & 8 & 8.8 \\
\hline 8.5 & 85.9 & 5.6 & 0 & 8.5 & 9.4 \\
\hline 9 & 91.0 & 0 & 0 & 9 & 9.9 \\
\hline 9.5 & 89.9 & 0 & 0.6 & 9.5 & 10.5 \\
\hline 10 & 88.8 & 0 & 1.2 & 10 & 11.0 \\
\hline 10.5 & 87.6 & 0 & 1.9 & 10.5 & 11.6 \\
\hline 11 & 86.5 & 0 & 2.5 & 11 & 12.1 \\
\hline 12 & 84.3 & 0 & 3.7 & 12 & 13.2 \\
\hline 13 & 82.1 & 0 & 4.9 & 13 & 14.3 \\
\hline 14 & 79.8 & 0 & 6.2 & 14 & 15.4 \\
\hline 15 & 77.6 & 0 & 7.4 & 15 & 16.5 \\
\hline 16 & 75.4 & 0 & 8.6 & 16 & 17.6 \\
\hline 17 & 73.1 & 0 & 9.9 & 17 & 18.7 \\
\hline 18 & 70.9 & 0 & 11.1 & 18 & 19.8 \\
\hline 19 & 68.7 & 0 & 12.3 & 19 & 20.9 \\
\hline 20 & 66.4 & 0 & 13.6 & 20 & 22.0 \\
\hline 21 & 64.2 & 0 & 14.8 & 21 & 23.1 \\
\hline 22 & 62.0 & 0 & 16.0 & 22 & 24.2 \\
\hline 23 & 59.7 & 0 & 17.3 & 23 & 25.3 \\
\hline 24 & 57.5 & 0 & 18.5 & 24 & 26.4 \\
\hline 25 & 55.2 & 0 & 19.5 & 25 & 27.5 \\
\hline 26 & 53.0 & 0 & 21.0 & 26 & 28.6 \\
\hline 27 & 50.8 & 0 & 22.2 & 27 & 29.7 \\
\hline 28 & 48.5 & 0 & 23.5 & 28 & 30.8 \\
\hline 29 & 46.3 & 0 & 24.7 & 29 & 31.9 \\
\hline 30 & 44.1 & 0 & 25.9 & 30 & 33.0 \\
\hline 31 & 41.8 & 0 & 27.2 & 31 & 34.1 \\
\hline 32 & 39.6 & 0 & 28.4 & 32 & 35.2 \\
\hline 33 & 37.4 & 0 & 29.6 & 33 & 36.3 \\
\hline 34 & 65.1 & 0 & 30.9 & 34 & 37.4 \\
\hline 35 & 32.9 & 0 & 32.1 & 35 & 38.5 \\
\hline
\end{tabular}

Figure S1. Preparation of $100 \mu \mathrm{L}$ of $\mathrm{L}_{3}$ phase samples in function of the required volume fraction $\Phi$. For samples prepared $\beta-\mathrm{OG}$, solution S1 ( $\beta$-OG 0.9\% (w/v), $\mathrm{NaCl} 100 \mathrm{mM}$, buffer), solution S2 ( $\mathrm{NaCl} 100 \mathrm{mM}$, buffer) and solution S3 ( $\beta-\mathrm{OG} \mathrm{9 \%} \mathrm{(w/v),} \mathrm{NaCl} 100 \mathrm{mM}$, buffer) were mixed with the proper amount of $\mathrm{C}_{12} \mathrm{E}_{5}$ into glass vials. Depending on the room temperature, the $\mathrm{C}_{12} \mathrm{E}_{5}$ stock could be solid or liquid. When solid, it was heated a few minutes 
and turned liquid before sample preparation. We used various phosphate buffers at a concentration of $50 \mathrm{mM}$. We checked that the properties of the phase were not altered at $\mathrm{pH}$ between 4 and 10, or by adding Glycerol up to $5 \%$, or by changing buffer or $\mathrm{NaCl}$ concentrations up to $200 \mathrm{mM}$. To prepare samples with DDM, CYMAL-4 and CYMAL-5 cosurfactants, $\beta$-OG was replaced by the co-surfactant in solutions $S 1$ and $S 3$. 